\title{
INSTITUCIONALIZAÇÃO E EXECUÇÃO DAS POLÍTICAS PÚBLICAS DE ECONOMIA SOLIDÁRIA NO BRASIL
}

\author{
Fernanda Abreu Nagem
}

\author{
Sandro Pereira Silva
}

\begin{abstract}
RESUMO
O artigo investiga a política pública de economia solidária no governo federal, implementada a partir de 2003 com a criação da Secretaria Nacional de Economia Solidária (SENAES), visando analisar com que mecanismos a temática se converte em política pública no âmbito do governo federal. Partindo do modelo teórico de Kingdon (1995), o artigo analisa, em primeiro lugar, o processo político (em sentido lato) que sucedeu sua inserção como política pública para a geração de trabalho e renda. A seguir, analisa-se os projetos e ações desenvolvidas no programa entre 2003 e 2010, com ênfase nas suas diretrizes, estrutura interna, dotação orçamentária e capacidade de execução. Finalmente, o artigo analisa as parcerias engendradas pelo SENAES com outros programas governamentais que fazem interface com a economia solidária, com vistas a aumentar a aderência do tema no interior do governo federal. A análise sugere que o modelo de Kingdon explica o processo de inserção da economia solidária como política pública em 2003, ainda que essa inserção seja apenas uma etapa do seu ciclo. Definida sua constituição normativa, nota-se uma disputa do programa no interior do governo: passados oito anos, não se observou uma intervenção efetiva do governo ao ponto de consolidar as práticas socioeconômicas - difundidas pela economia solidária - como estratégia real para a inserção no mundo do trabalho, ou mesmo criar um ambiente institucional que incentive a formalização dos grupos econômicos associativos existentes. Em que pese sua baixa dotação orçamentária face a outros programas do MTE, o PESD não se constituiu em um programa de referência para uma nova estratégia de desenvolvimento, mesmo que a SENAES tenha conseguido aglutinar ao seu entorno forças sociais e políticas importantes para a defesa da economia solidária enquanto política pública. O trabalho situa e problematiza a inserção e a condução das politicas de economia solidaria no governo federal, revelando que a temática não ascendeu a macrossistema político, gravitando em um campo marginal, fora desse núcleo, em busca de espaço para sua valorização interna. Enquanto ela for encarada meramente como uma alternativa paliativa ao problema do desemprego, dificilmente conseguirá enfrentar os antagonismos e conflitos de interesse que impedem sua viabilização.
\end{abstract}

PALAVRAS-CHAVE: economia solidária; políticas públicas; trabalho e renda; finanças públicas; cooperativismo.

\section{INTRODUÇÃO ${ }^{1}$}

A desestruturação do mercado de trabalho e a crise do emprego assalariado na década de 1990 fez emergir no país uma série de discussões sobre quais os rumos e estratégias a serem tomadas para a inclusão produtiva de uma grande parcela da sociedade, bem como qual o papel que o Estado deveria assumir nesse processo. Muitos acadêmicos e grupos sociais passaram a propalar a necessidade de apoiar e fomentar outras formas de trabalho além do emprego assalariado. Foi nesse contexto que a temática da economia solidária, cujo conceito compreende as diversas formas de organização econômica baseadas no trabalho coletivo e na autogestão administrativa, ganhou densidade acadêmica e foi também amplamente adotada pelos movimentos sociais e sindicais no final da década,

\footnotetext{
1 Gostaríamos de agradecer aos pareceristas anônimos da Revista de Sociologia e Política pela contribuição a este artigo.
}

chegando inclusive a ser inserida na agenda de políticas públicas em alguns estados e municípios.

Este trabalho tem como foco de investigação a política pública de economia solidária no governo federal, que começou a ser implementada em 2003 com a criação da Secretaria Nacional de Economia Solidária (Senaes), como órgão componente do Ministério do Trabalho e Emprego (MTE). O principal objetivo é analisar se a economia solidária foi adotada como diretriz estratégica para as ações de geração de trabalho e renda do governo federal. Parte-se da premissa de que a temática da economia solidária, embora tenha se institucionalizado politicamente no governo federal brasileiro desde 2003, permanece como uma estratégia marginal em termos de foco de intervenção governamental para a temática da geração de trabalho e renda no país, voltada fortemente para a via do mercado de trabalhado assalariado.

Para alcançar o objetivo proposto, dividiu-se a análise em três partes. Primeiramente, buscou-se 
entender, à luz do modelo teórico de Kingdon (1995), como a temática da economia solidária foi inserida na agenda do novo governo federal em 2003, analisando o processo social, político e econômico no país no período que sucedeu sua inserção como política pública de geração de trabalho e renda. Segundo, com base nos principais instrumentos de planejamento do ciclo do orçamento público no Brasil, analisou-se quais os principais projetos e ações desenvolvidas no Programa Economia Solidária em Desenvolvimento, entre os anos 2003 e 2010, focando suas diretrizes, sua estrutura interna, sua dotação orçamentária e capacidade de execução. Por último, verificou-se também quais as principais parcerias que a Senaes conseguiu engendrar nesses anos para o desenvolvimento de outros programas que fazem interface com a economia solidária, e que assim pudessem aumentar a aderência do tema no interior do governo.

Como instrumentos de análise, realizou-se uma pesquisa bibliográfica sobre os temas economia solidária e políticas públicas, a fim de entender como e sob quais circunstâncias esses temas uniram-se como proposta de geração de trabalho e renda no país. Outros documentos analisados foram: (i) os Planos Plurianuais de 2004-2007 e 2008-2011; (ii) os relatórios de execução da Lei Orçamentária Anual entre 2003 e 2010 e (iii) documentos oficiais da Senaes. Também se realizou uma entrevista semiestruturada com um dos diretores da Senaes, com vistas a obter maiores esclarecimentos sobre os processos políticos e as dificuldades internas vivenciadas nesse período.

\section{CONTEXTO GERAL DA ECONOMIA SOLIDÁ- RIA NO BRASIL}

\section{II.1. Definições e concepções de economia solidária}

A temática da economia solidária surgiu no campo acadêmico brasileiro no final da década de 1990. Podese dizer que o enfoque privilegiado pelos estudiosos desde então é o de representar as formas de organização do trabalho, contrastante com a relação mais comum e usual do patrão e empregado, norteadas por princípios como a autogestão administrativa e de solidarização de capital.

De maneira mais geral, a economia solidária pode ser definida como o conjunto das atividades que contribuem para a democratização econômica a partir do engajamento dos indivíduos em formas coletivas de organização do trabalho. Segundo Singer (2002), são múltiplas as iniciativas que a caracterizam, tais como as empresas autogestionárias, com seus coletivos de trabalhadores organizados com base na democracia nas tomadas de decisões, além de diversas outras formas de associativismo e cooperativismo na organização sócio-produtiva de caráter suprafamiliar, caracterizando um verdadeiro "polimorfismo" organizacional. Os empreendimentos de economia solidária são suas células básicas, e têm como princípios básicos: $(i)$ posse coletiva dos meios de produção pelas pessoas que as utilizam para produzir; (ii) gestão democrática da empresa ou por participação direta ou por representação; (iii) repartição da receita líquida entre os cooperadores; $(i v)$ destinação do excedente econômico por critérios acertados entre todos os cooperadores.

Embora esses empreendimentos busquem uma organização que vise sua inserção econômica, no intuito de produzir um bem, prestar um serviço, permitir compras conjuntas, intermediar microfinanças ou qualquer outra relação de fins econômicos, a dimensão política também está fortemente presente em sua atuação. Isso se traduz tanto no envolvimento dos participantes em todas as questões relativas ao empreendimento e suas decisões, quanto no seu relacionamento com as questões locais e comunitárias nas quais estão inseridos (FRANÇA FILHO \& LAVILLE, 2006), destaque para a organização, em todos os estados da federação, dos chamados Fóruns de Economia Solidária, espaços de atuação e articulação dos diversos segmentos envolvidos na temática da economia solidária existes no país (NAGEM, 2011).

Da mesma forma que a economia solidária, englobando todo o seu rol de iniciativas autogestionárias dos trabalhadores, passou a ganhar visibilidade a partir da crise do trabalho na década de 1990, outras respostas a essa crise também emergiram, tais como a terceirização e a flexibilização do trabalho. Nessa época surgiram várias cooperativas de trabalho, conhecidas como "coopergatos", que nada mais eram do que empresas disfarçadas para isentarem seus verdadeiros donos de gastos com obrigações trabalhistas. Diferentemente dessas relações que intensificaram a geração de postos de trabalho precários e a exclusão social, as iniciativas de economia solidária apresentaram, em sua essência, a busca de novas formas de regulação com base em uma auto-organização econômica e política da sociedade, sob o recurso da reciprocidade ${ }^{2}$. Segundo Leite, ao almejar uma incidência multidimensional na esfera da organização do trabalho, a economia solidária passa a ter como especificidade: “[...] combinar dinâmicas de iniciativas privadas com propósitos centrados não no lucro, mas no interesse coletivo. A razão econômica é acompanhada por uma finalidade social que consiste em produzir vínculos sociais e solidários, baseados numa solidariedade de

\footnotetext{
2 "O recurso à reciprocidade consiste em tratar coletivamente problemas cotidianos na esfera pública, em vez de cada um tentar resolvê-los individualmente na esfera privada" (LEITE, 2009, p. 34).
} 
proximidade; o auxílio mútuo e a reciprocidade estariam, assim, no âmago da ação econômica" (LEITE, 2009, p. 34).

No entanto, existe na literatura uma divergência de entendimentos sobre o papel das cooperativas e sua capacidade de transformação da realidade social. Tal divergência não é nova e nem tampouco simples. Ela remete à velha polêmica de Marx com o movimento cooperativista europeu no século XIX, quando Marx afirmou que o cooperativismo, embora consiga romper com o autoritarismo da divisão interna do trabalho, ao implementar a autogestão no processo produtivo, ele não romperia com a anarquia da divisão social do trabalho, já que seus produtos adentram em um sistema mercantil de trocas, devendo então seguir as mesmas regras de mercado que as demais empresas capitalistas (HADDAD, 2003). Nem por isso, Marx deixou de reconhecer a importância do cooperativismo para as conquistas da classe trabalhadora européia em sua época, mas ressaltava a necessidade de uma maior escala de atuação do cooperativismo, como frisou Fedosseiev (1973, p. 484): "Marx apontava os êxitos alcançados pelo movimento operário neste período: a conquista da jornada de trabalho de dez horas e o crescimento do movimento cooperativo. Se a limitação da jornada de trabalho pela lei refutava o dogma da burguesia liberal sobre a inadmissibilidade da intervenção do Estado nas relações econômicas, os êxitos do cooperativismo mostravam que os operários eram capazes de organizar a produção sem os capitalistas. No entanto, no quadro da sociedade capitalista, o cooperativismo não poderá melhorar sensivelmente a situação da classe operária. $\mathrm{O}$ trabalho cooperativo só pode ser uma alavanca da libertação dos trabalhadores se, escrevia Marx, for desenvolvido à escala nacional, com meios nacionais".

Entre os debates atuais no campo da economia solidária, Leite (2009) observou a existência de três correntes. A primeira argumenta que as experiências de economia solidária possuem princípios e práticas avessos ao do sistema capitalista (MANCE, 1999; SINGER 2002). Por sua vez, a segunda corrente reúne estudiosos que interpretam as iniciativas desse campo como um modelo de produção que, como tal, convive com o sistema capitalista e com ele relaciona-se, assim como outros existentes (RAZZETO, 1997; GAIGER, 2003; LAVILLE \& FRANÇA FILHO, 2004). Por fim, há um grupo de estudiosos que interpreta a economia solidária simplesmente como uma reação às crises do sistema capitalista e, dessa forma, suas iniciativas são efêmeras e tendem a desaparecer quando tais crises cessam (CASTEL, 1998; QUIJANO, 2002).

Para fins deste trabalho, entende-se que, por um lado, seria um erro desconsiderar o esforço de uma parcela considerável de pessoas que se organizam de modo coletivo para buscar sua inserção socioeconômica, além dos diversos movimentos sociais que defendem essa forma de organização, mesmo com todas as dificuldades que esses grupos encontram. Por outro lado, não existem indicadores para uma defesa da economia solidária como um novo modo de produção, totalmente alheio ao capitalismo, dada a realidade político-institucional vigente no Brasil e na maioria dos países. Assim, tende-se a aproximar da segunda vertente apresentada por Leite (2009), de que a economia solidária é uma entre as várias formas de produção existentes no interior do capitalismo, embora parta de diretrizes antagônicas a esse sistema. Mas, ao mesmo tempo, compartilha-se também da visão de Marx, de que a solidariedade deve transcender ao nível micro do empreendimento, de modo a criar redes e encadeamentos produtivos cooperativos. Para isso, torna-se essencial a adoção, por parte do Estado, do paradigma cooperativista como uma matriz importante de atuação.

\section{II.2. Trabalho, políticas públicas e economia solidária}

A discussão teórica que envolve a definição de política pública é bastante ampla. Segundo Souza (2006), esse é um campo do conhecimento que busca colocar o governo em ação, e ao mesmo tempo, analisar essa ação. Ainda de acordo com a autora, a formulação de políticas públicas constitui-se no estágio em que governos democráticos traduzem seus propósitos e plataformas eleitorais em programas e ações, envolvendo níveis de decisão e atores variados, que produzirão resultados ou mudanças no mundo real. Em resumo, uma política pública diz respeito ao que o governo pretende fazer e o que ele realmente faz.

No Brasil, as profundas mudanças no cenário sóciopolítico a partir da década de 1980 , que resultaram no processo de redemocratização, no que diz respeito principalmente à retomada de eleições diretas para todos os níveis de governo, e no processo de descentralização fiscal, prevista na Constituição Federal de 1988, modificaram profundamente a natureza e a forma de implementação de políticas públicas. Todo esse processo acarretou em uma grande transformação institucional sofrida pela estrutura organizacional do sistema de proteção social brasileiro. As políticas públicas nas áreas de saúde, assistência social, habitação, saneamento e educação fundamental pas-saram a ser implantadas, paulatina e progressivamente, por meio de programas de descentralização que, aos poucos, transferiram um conjunto significativo de atribuições de gestão aos entes federativos subnacio-nais. Os estados e municípios passaram a assumir a gestão de políticas públicas de três diferentes formas: (i) por iniciativa própria; (ii) por adesão a um programa proposto por outro nível, 
mais amplo, de governo; (iii) ou, ainda, por imposição constitucional (ARRETCHE, 2002).

O contexto da reforma administrativa do Estado brasileiro, a partir de meados da década de 1990, passou a envolver também a descentralização de recursos dos órgãos governamentais para entidades privadas sem fins lucrativos, por meio de diversas formas de parceria e contratos de gestão. De acordo com Souza (2006), o conjunto das modificações nesse período fez emergirem novas institucionalidades políticas, sobretudo, na esfera local. Assim, o processo de descentralização ocorrido no Brasil, não deve ser interpretado como uma questão exclusivamente administrativa, mas, sobretudo, de natureza política.

No entanto, no Brasil a década de 1990 não foi marcada somente por mudanças políticas. Fortes alterações também ocorreram na condução da economia por parte do Estado, evidenciando a chamada política de "estado mínimo", sob a qual o Estado deveria intervir apenas de modo a regular a atuação dos mercados, responsáveis pela alocação ótima dos fatores de produção. Deriva dessa época o processo de reestruturação produtiva que afetou diretamente a oferta de emprego industrial, gerando uma imensa massa de desempregados que não conseguiam mais inserir-se no mercado de trabalho (MATTOSO, 1999).

Com isso, a questão do trabalho voltou a estar no centro das discussões do desenvolvimento brasileiro, com o Estado sendo o responsável por planejar as ações com vistas a criar um ambiente favorável para 0 combate ao desemprego. No entanto, o campo das políticas públicas na área de trabalho vislumbrava exclusivamente a esfera do emprego formal, sem aterse a possibilidades de geração de trabalho e renda fora do paradigma da relação assalariada clássica. As ações públicas para o emprego no Brasil enquadraram-se na vertente tradicional do Estado de Bem-Estar Social, baseada no tripé seguro-desemprego, qualificação profissional e intermediação de mão de obra, constituindo assim o Sistema Público de Emprego. Para assegurar o financiamento desse sistema, foi criado, em 1990, de acordo com a Lei n. 7998 o Fundo de Amparo ao Trabalhador (FAT).

No entanto, a ação pública sobre esse sistema não foi capaz de refrear o avanço do desemprego e da informalização da economia ao longo da década de 1990. A atuação livre de sindicatos e movimentos sociais os mais diversos, possibilitada pelo fim do regime militar, aumentou a pressão social sobre o governo federal para novas ações nesse campo, inclusive com a adoção de políticas que fosse além "da noção de políticas de emprego para a idéia de políticas de geração de trabalho e renda" (FRANÇA
FILHO, 2006, p. 261). Surgiram então os primeiros programas de financiamento subsidiado para pequenos negócios, tanto em áreas urbanas (Programa Nacional de Geração de Trabalho e Renda - Proger) como em áreas rurais (Programa Nacional de Fortalecimento da Agricultura Familiar - Pronaf).

Em paralelo a isso, muitos grupos sociais também advogavam uma maior atenção governamental para iniciativas de apoio ao cooperativismo, a fim de viabilizálo como uma opção viável de organização econômica de grupos populares que, por alguma razão, não estavam inseridos no mercado de trabalho assalariado. Assim, a temática da economia solidária passou a adentrar o debate sobre a atuação do Estado no mundo do trabalho como estratégia de combate à crise do desemprego $^{3}$, até chegar ao ponto de alguns estados e municípios começarem a incluir em sua agenda governamental ações de apoio aos grupos e iniciativas de economia solidária. De acordo com França Filho (idem), as políticas de economia solidária inauguraram no Brasil uma nova forma de intervenção do Estado na geração de trabalho e renda que vai além da relação assalariada.

O primeiro programa realmente estruturado surgiu com a ascensão do Partido dos Trabalhadores ao governo do Rio Grande do Sul (1998-2002): trata-se do Programa de Economia Popular Solidária (Ecopopsol), no governo estadual. Esse programa foi pioneiro no país na definição da economia solidária como estratégia de política pública. Entre seus principais eixos estavam: (i) formação em autogestão; (ii) capacitação profissional; (iii) financiamento; (iv) comercialização e $(v)$ incubação de empreendimentos. No âmbito municipal, um dos programas iniciais de maior destaque foi o Programa Oportunidade Solidária, da Prefeitura Municipal de São Paulo, especialmente devido ao grande desafio de ser implementado na maior metrópole do país (SILVA, 2010).

Em junho de 2003 a economia solidária foi institucionalizada no Brasil a nível federal, pela Lei n. 10683 e o Decreto n. 4764 , com a criação da Secretaria Nacional de Economia Solidária (Senaes), pasta ligada ao Ministério do Trabalho e Emprego (MTE). É importante frisar que a Senaes surgiu a partir da mobilização de vários atores sociais organizados em torno da temática da economia solidária e que atuam em diversas áreas da sociedade brasileira.

\footnotetext{
3 Interessante perceber, principalmente do início do século XIX em diante, a mudança de discurso no que diz respeito à natureza das políticas públicas de economia solidária: de geração de trabalho e renda para "estratégia de desenvolvimento", como reforçaram a I e II Conferência Nacional de Economia Solidária e a V Plenária Nacional de Economia Solidária.
} 


\section{A ECONOMIA SOLIDÁRIA NA AGENDA GOVERNAMENTAL}

Nesta sessão são apresentados os resultados obtidos quanto à análise da inserção da temática "Economia Solidária" na agenda governamental, ou seja, como objeto para a definição de políticas públicas. Entre as matrizes de análise de políticas públicas existentes, uma que vem ganhando boa expressão é a elaborada por Kingdon (1995), conhecida como Modelo de Fluxos Múltiplos (Multiple Streans Framework), utilizado justamente para o estudo dos fatores determinantes para a formação da agenda governamental. Por isso, esse modelo foi adotado como matriz analítica para os propósitos deste estudo.

\section{III.1. O modelo de Kingdon para a definição de agenda governamental}

O modelo de Kingdon é utilizado para explicar as decisões e definições de agendas de políticas públicas por governos nacionais. Para Kingdon (idem), a agenda governamental é definida a partir de um conjunto de temas ou problemas em pauta sob um determinado momento que demandam a atenção da equipe de governo e seus assessores. No entanto, dada a grande variedade de questões que vão surgindo, somente algumas delas serão de fato consideradas e inseridas na agenda de ação governamental (agenda-setting), ou seja, serão englobadas como políticas públicas e determinarão procedimentos e especificação de alternativas.

O processo de definição de uma agenda governamental é afetado por processos pelos quais os itens da agenda conseguem o destaque necessário, levando à sua implementação. Esses processos envolvem três fluxos decisórios (streams), a saber: (i) problemas (problems), que podem ser identificados por meio de indicadores, crises ou feedback de outras ações em curso; (ii) soluções ou alternativas (policies), que são debatidas em comunidades específicas de especialistas e são definidas a partir de sua viabilidade técnica e financeira; (iii) político (politics), que vai envolver o ambiente de "humor" nacional (national mood), caracterizado por uma situação em que diversas pessoas compartilham as mesmas questões durante um determinado período, as forças políticas organizadas que determinam o apoio ou oposição a uma questão em pauta e as mudanças no interior do próprio governo. Há uma relativa independência entre os três fluxos, que se desenvolvem segundo suas próprias dinâmicas.
A convergência dos três fluxos em um dado momento abre uma "janela política" no processo de definição de agenda e possibilita a origem de um novo item de política pública.

Outro componente importante no modelo de Kingdon (idem) é a atuação dos chamados "empreendedores políticos", que estão sempre prontos para atuar no momento em que uma janela política se abre. Em geral, são especialistas que gozam de boa reputação, habilidade de negociação ou detêm certa popularidade política. Além disso, estão dispostos a investir recursos como tempo, energia e dinheiro para promover uma idéia e influenciar o processo de formulação de políticas, unindo soluções a problemas.

\section{III.2. A inserção do Programa Economia Solidária em Desenvolvimento na agenda}

De acordo com o modelo de Kingdon (idem), podese distinguir claramente a interação entre os três fluxos que propiciaram a inserção da economia solidária na agenda governamental em 2003, culminando com a criação da Senaes. Seguindo sua sequência metodológica, o fluxo dos problemas é o primeiro a ser analisado.

O modelo aponta três maneiras pelas quais um problema pode ser reconhecido como importante (indicadores, eventos focalizadores e feedback), ao ponto de buscar-se soluções via políticas públicas. No caso da economia solidária o que mais pesou foram os indicadores referentes ao mercado de trabalho no início do século XXI. O processo de reestruturação produtiva no Brasil após a abertura comercial de sua economia no começo da década de 1990, aliado à nova orientação de atuação do Estado, que diminuiu drasticamente seu poder de contratação de pessoal, resultaram em uma elevação crescente tanto no nível de desemprego quanto no grau de informalidade no mercado de trabalho brasileiro. Com isso, enquanto uma parcela significativa da população brasileira não conseguia encontrar trabalho remunerado, uma boa parte dos que conseguiam o faziam por meio de ocupações não formalizadas, sem acesso aos direitos trabalhistas básicos conquistados ao longo do século. A Tabela 1, abaixo, ilustra esse fenômeno, ao evidenciar que o desemprego subiu de um patamar em torno de $7 \%$ em 1992 para $10,5 \%$ em 2002 , aumentado $50 \%$ no período, enquanto que a informalidade cresceu de $40 \%$ para $47,2 \%$ no mesmo período. 
TABELA 1 - TAXAS DE DESEMPREGO E INFORMALIDADE NO BRASIL: 1992 A 2002 (\%)

\begin{tabular}{|l|c|c|c|c|c|c|c|c|c|}
\hline Ano & $\mathbf{1 9 9 2}$ & $\mathbf{1 9 9 3}$ & $\mathbf{1 9 9 5}$ & $\mathbf{1 9 9 6}$ & $\mathbf{1 9 9 7}$ & $\mathbf{1 9 9 8}$ & $\mathbf{1 9 9 9}$ & $\mathbf{2 0 0 1}$ & $\mathbf{2 0 0 2}$ \\
\hline Desemprego aberto & 7,2 & 6,8 & 6,7 & 7,6 & 8,5 & 9,7 & 10,4 & 10,0 & 10,5 \\
Informalidade & 39,9 & 40,9 & 42,6 & 43,2 & 43,4 & 43,9 & 45,7 & 46,5 & 47,2 \\
\hline
\end{tabular}

FONTE: IPEA (2004).

A combinação entre desemprego e informalidade tem um reflexo direto no aumento da pobreza e em todos os riscos sociais que dela são decorrentes, o que, por si só, já se constituem em um mecanismo forte de pressão para uma atuação mais proativa do Estado brasileiro para resolver essa problemática.

Em termos do fluxo de soluções, conforme o segundo fluxo do modelo de Kingdon (1995), pode-se dizer que a comunidade acadêmica foi a principal responsável pela consolidação e disseminação do conceito de economia solidária para os meios político e social. Essa temática foi inserida na segunda metade da década de 1990, em meio ao debate sobre alternativas ao desmantelamento do mercado de trabalho no Brasil e à crise do Estado do Bem-Estar Social, em que voltaram a ganhar destaque temas que envolviam a organização de trabalhadores em iniciativas cooperativistas e autogestionárias. O termo economia solidária passou a dar uma identidade comum a essas iniciativas, o que proporcionou a junção de diferentes grupos em torno do mesmo conceito. Esse debate ocorreu não apenas no Brasil, mas simultaneamente em vários países da Europa e também da América Latina, fortalecendo ainda mais sua importância.

Um indicador para esse forte enraizamento acadêmico da economia solidária é o número de trabalhos de conclusões de cursos de pós-graduação no país que apresentavam seu tema principal de alguma maneira ligado à economia solidária. Bertucci (2010), ao pesquisar no Banco de Teses da Capes, verificou que, a partir do primeiro trabalho publicado em 1998, o número de teses e dissertações cresceu muito nos anos posteriores, totalizando 226 entre os anos de 1998 a 2007. Em 2003, justamente no ano de criação da Senaes, o número de estudos acadêmicos quase se quadruplicou com relação ao ano anterior. Uma das explicações do autor para esse aumento no número de estudos acadêmicos foi a proliferação das Incubadoras Tecnológicas de Cooperativas Populares (ITCPs), comandadas por professores universitários, e que suscitaram vários grupos de pesquisa e extensão nos centros de ensino superior. É interessante também destacar que esses estudos espalharam-se por diversas áreas, tais como: Ciências Sociais Aplicadas, Engenharias, Direito, Ciência Políti- ca, Geografia, Enfermagem, Psicologia, entre outras.

Toda essa valorização da temática da economia solidária no meio acadêmico foi de grande importância para seu fortalecimento também no meio político, que compõe o $3^{\circ}$ fluxo de Kingdon. Diversas organizações da sociedade civil passaram a defender o trabalho autogestionário sob a concepção da economia solidária. Entre elas, destacam-se: a Cáritas Brasileira, ligada à Igreja Católica, que já tinha um histórico de atuação em projetos de desenvolvimento alternativos; a Associação Nacional de Trabalhadores e Empresas de Autogestão (Anteag), formada no início da década de 1990, no intuito de apoiar as empresas recuperadas por trabalhadores na região Sul; e a Agência de Desenvolvimento Solidário (ADS), ligada à Central Única dos Trabalhadores (CUT), que surgiu para difundir a questão do cooperativismo no meio sindical. Além dessas organizações citadas, predominantemente urbanas, os grupos sociais do meio rural também passaram a adotar o termo economia solidária em suas bandeiras de luta, como no caso da Confederação Nacional dos Trabalhadores da Agricultura (Contag), a Federação dos Trabalhadores na Agricultura Familiar (Fetraf), e o Movimento dos Trabalhadores Rurais sem Terra (MST).

Representantes de grande parte desses grupos sociais citados acima encontraram-se no II Fórum Social Mundial, em Porto Alegre (RS), em janeiro de 2003, que resultou na formação de um Grupo de Trabalho Nacional de Economia Solidária (GT de Economia Solidária). A atuação do GT foi responsável pela reivindicação e posterior negociação direta, junto ao recém governo federal eleito em 2002, de um espaço institucional para a economia solidária na estrutura de governo. Em junho desse mesmo ano, ocorreu em Brasília a III Plenária Nacional de Economia Solidária, que encaminhou como demandas ações como a criação de um marco legal específico para a economia solidária, assim como atividades de formação, finanças solidárias e apoio à produção e comercialização. Todos esses temas foram incorporados posteriormente como ações do Programa Economia Solidária em Desenvolvimento (PESD), configurando-se como seus eixos centrais. Nesse evento também foi criado o Fórum Brasileiro de Economia Solidária (FBES), que congrega as 
organizações da sociedade civil envolvidas na temática da economia solidária.

Outra força social que conferiu uma importância significativa para que a economia solidária se constituísse nacionalmente enquanto uma "marca política" foi o Partido dos Trabalhadores (PT). Até 2003, todas as experiências de políticas públicas estaduais e municipais de economia solidária haviam sido implementadas pelo PT (SILVA, 2010). A própria origem do termo economia solidária surgiu no programa de campanha do partido nas eleições municipais para a prefeitura de São Paulo, em 1996 (COSTA, 2008). Esse reconhecimento do PT foi crucial, já que o país entrava em um momento de mudança de governo em 2003, quando tomou posse o presidente eleito Luis Inácio Lula da Silva.

Mas a eleição do candidato do PT para presidente não foi, por si só, suficiente para a inclusão da economia solidária na agenda do novo governo. Como lembra Kingdon (1995) em seu modelo, para a abertura da janela de oportunidade é imprescindível o papel de indivíduos com competência reconhecida que defendem ardorosamente o tema junto ao governo, chamadas pelo autor de "empreendedores".

O principal empreendedor para a abertura da janela política no governo Lula para a economia solidária foi Paul Singer, professor da Universidade de São Paulo (USP), com importância fundamental na convergência dos três fluxos (problemas-soluções-político). Como teórico do mundo do trabalho, de inspiração marxista, sempre foi um crítico do neoliberalismo, que reduzia o poder do Estado de intervir na realidade social. Singer escreveu vários livros abordando temáticas que versavam sobre economia política, a formação da classe trabalhadora no Brasil, demografia e cooperativismo. A partir da década de 1990, passou a ser o principal teórico e defensor das estratégias cooperativistas para a organização dos trabalhadores pobres contra o desemprego e a exclusão social. Para complementar, Singer é também um quadro histórico do PT, com experiência administrativa na prefeitura municipal de São Paulo, e muito próximo dos movimentos sindicais e sociais. Esses fatos lhe legitimaram para ser o principal porta-voz dos grupos sociais que defendiam a inserção da economia solidária no novo governo.

A junção de todos esses fatos proporcionou a criação, em 2003, da Secretaria Nacional de Economia Solidária (Senaes), que ficou abrigada no Ministério do Trabalho e Emprego (MTE), e Paul Singer foi escolhido pelo presidente Lula para ser o secretário da pasta.

\section{ANÁLISE DA EXECUÇÃO ORÇAMENTÁRIA}

A definição dos instrumentos de planejamento orçamentário fornece um importante indicativo sobre as prioridades que o governo vai adotar ao longo de sua vigência, já que esses instrumentos apontam quais itens irão compor a agenda governamental, quais as ações receberão dotação orçamentária (e de que magnitude), entre outras informações valiosas para a análise de políticas públicas. Especificamente para os objetivos deste trabalho, as análises recaíram na definição do programa Economia Solidária e Desenvolvimento (PESD) nos PPAs de 2004-2007 e 2008-2011, bem como nas LOAs de 2003 a 2010. Com isso, espera-se entender a dimensão de importância dada à política de economia solidária pelo governo federal, verificando seus principais projetos, a estrutura institucional, as alterações programáticas ao longo dos anos, sua importância relativa aos demais programas do Ministério do Trabalho e Emprego e a execução orçamentária auferida. Também verificou-se quais as principais parcerias com outros agentes governamentais construídas pela Senaes em torno da temática da economia solidária em outros programas, para que se possa diagnosticar a transversalidade de sua aderência no interior do governo.

\section{IV.1. O planejamento do ciclo orçamentário público no Brasil}

As diretrizes que definem o ciclo orçamentário das políticas públicas no Brasil foram definidas na Constituição Federal de 1988, sendo contempladas posteriormente em seus desdobramentos, como a Lei de Responsabilidade Fiscal (LRF). Pelo artigo n. 165 da Constituição Federal, estabeleceu-se que o orçamento público é um processo integrado de alocação de recursos, compreendendo as atividades de planejamento e orçamento, com base em três instrumentos de iniciativa do poder Executivo nacional, que são: o Plano Plurianual de Aplicações (PPA), a Lei de Diretrizes Orçamentárias (LDO) e a Lei Orçamentária Anual (LOA). Segundo Oliveira (2009), o novo ciclo orçamentário recuperou o orçamento como instrumento de democracia, de controle do Estado e de planejamento.

Entre os três instrumentos citados, o PPA é o de maior alcance temporal e corresponde à duração de um mandato de governo, ou seja, quatro anos. Podese dizer que seu principal objetivo é definir os programas, metas e prioridades da administração, bem como os resultados esperados pela administração federal. O PPA é composto por uma base estratégica, que apresenta os principais objetivos, diretrizes e prioridades que nortearão o plano de governo nos próximos quatro anos, e pelos programas, que são as políticas públicas a serem implementadas nas mais diversas áreas de abrangência governamental. Os programas subdividem-se em projetos e atividades, que indicam o que cada órgão responsável irá executar de fato para a implementação daquele programa. 
Com relação à LDO, pode-se dizer que ela cumpre um papel de conexão entre o plano estratégico das ações no PPA e o plano operacional do orçamento a ser executado. Com base no artigo n. 165 da Constituição, o objetivo da LDO é orientar a elaboração da LOA, dispondo sobre questões tributárias e fiscais no que tange às estruturas da administração pública federal. A LDO possui prazo de vigência anual.

Por fim, a LOA representa o orçamento negociado na fase de elaboração da LDO, compreendendo todas as despesas e receitas, e definindo isenções, anistias, subsídios e benefícios de natureza financeira. Ela é composta por três segmentos: orçamento fiscal, orçamento de investimento das empresas estatais e orçamento da seguridade social. Como o próprio nome diz, a LOA tem vigência anual, mas pode sofrer cortes ou contingenciamentos ao longo do exercício administrativo, de acordo com as diretrizes fiscais do governo.

\section{IV.2. Estratégias de intervenção e execução orça- mentária}

A Senaes trouxe em sua origem a expectativa de fortalecer as iniciativas de economia solidária na sociedade brasileira. Seu ano inicial, em 2003, foi de estruturação interna, da realização de interlocução com os diversos grupos da sociedade civil, com os demais setores do MTE e outros órgãos governamentais. Em 2004, a Senaes passou a contar com orçamento próprio, por meio da inserção no PPA da ação n. 1133 - Programa Economia Solidária em Desenvolvimento (PESD).

$\mathrm{O}$ orçamento da Senaes apresentou crescimento ao longo dos anos, embora tenha sofrido oscilações, como por exemplo, uma queda brusca de valor nos anos 2005 e 2006, recuperando-se novamente no ano seguinte e alcançando um valor de $\mathrm{R} \$ 45$ milhões em 2010. Porém, seus valores não alcançaram, em nenhum dos anos analisados, nem próximo a $1 \%$ do orçamento do MTE. Somando os valores dos sete anos em análise, o orçamento da Senaes representou apenas $0,09 \%$ do total do MTE, o que evidencia o papel marginal, em termos de recursos, que a economia solidária possui no âmbito das políticas do MTE. Como comparação, o programa de Qualificação Social e Profissional do MTE, por exemplo, recebeu dotação orçamentária em 2010 cinco vezes maior que o PESD.

Ao comparar o orçamento da Senaes entre os PPAs 2004-2007 e 2008-2011, nota-se que o segundo PPA apresentou um orçamento superior. De acordo com o diretor da Senaes, esse fato está ligado à mobilização dos atores sociais que defendem a temática da economia solidária junto ao Estado e à sociedade, dando-lhe maior visibilidade e peso político.

Além do valor do orçamento definido em cada exercício, outra questão importante diz respeito à sua execução orçamentária ${ }^{4}$. Pelas informações fornecidas abaixo, no Gráfico 1, enquanto o MTE conseguiu aumentar progressivamente seu percentual de execução ao longo dos anos, alcançando o índice de $97,8 \%$ no ano de 2010, a Senaes apresentou no mesmo período uma tendência de queda do seu percentual de execução orçamentária, chegando em 2010 ao seu menor valor, $25,3 \%$. Os dois anos em que a Senaes obteve o maior percentual de execução foram 2006 e 2007, justamente os anos em que a secretaria teve à sua disposição os menores valores orçamentários, se comparados aos anos seguintes (entre 2008 e 2010). Esses dados demonstram que a Senaes teve sérias dificuldades de execução de seu orçamento, principalmente ao longo do último PPA.

GRÁFICO 1 - PERCENTUAL DE EXECUÇÃO ORÇAMENTÁRIA: MTE E SENAES (2004-2010)

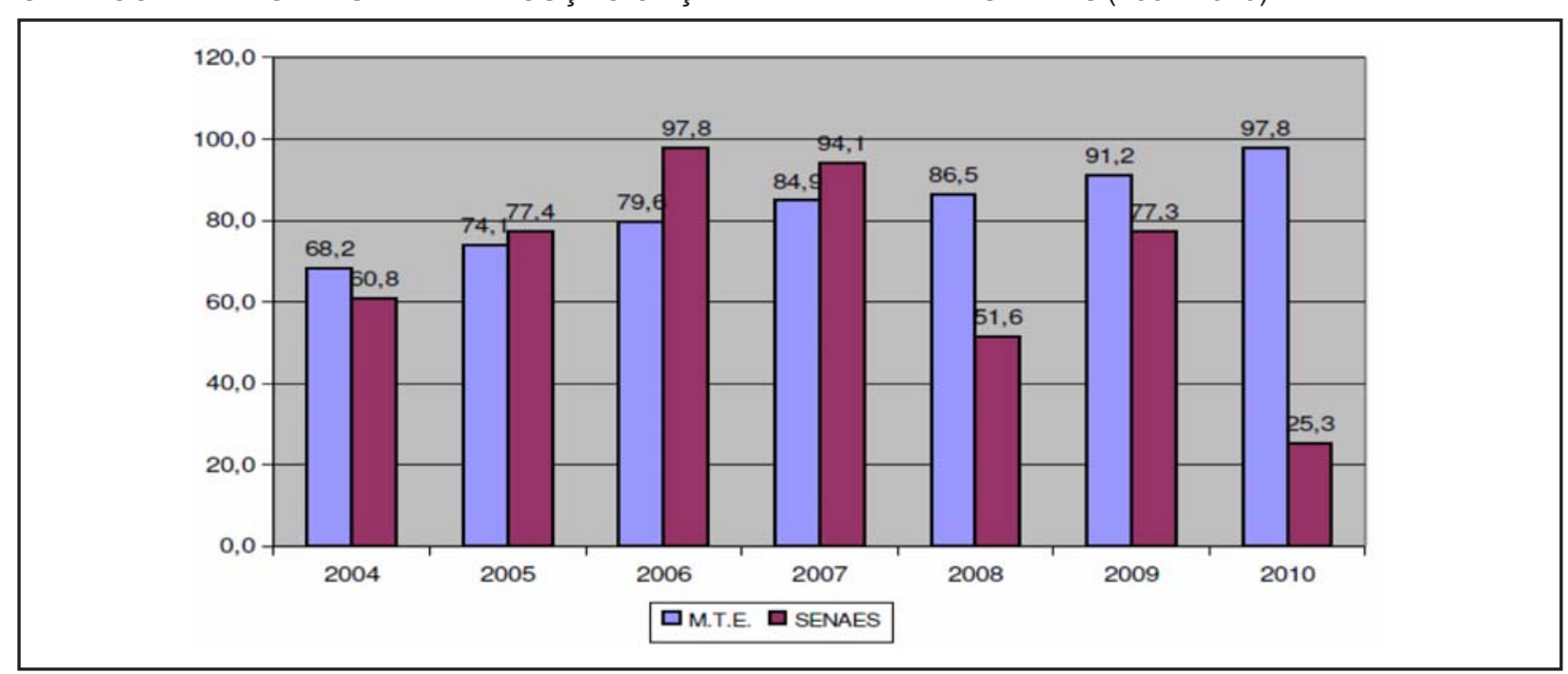

FONTE: Lei de Diretrizes Orçamentárias (2004-2010) (BRASIL. CÂMARA DOS DEPUTADOS, 2013). 
Quando questionado sobre quais seriam os fatores que estariam dificultando a execução orçamentária da Senaes, o diretor entrevistado disse ser necessário contextualizar politicamente os anos de maior dificuldade de execução e enumerou alguns fatores que levaram a tal situação. $O$ principal deles diz respeito à própria dinâmica de funcionamento do orçamento da União. Até se chegar ao recurso final para cada ação inserida no PPA, o orçamento, geralmente, sofre variações, conforme explicou no trecho a seguir: "Você tem a LOA, que é uma lei autorizativa para o governo federal [...], ela autoriza o poder executivo naquelas ações, naqueles programas e naquelas finalidades. $\mathrm{O}$ governo federal está autorizado pelo Congresso a executar até certo valor de recursos. Como isso sempre passa por modificações no Congresso, e por qualquer outro motivo conjuntural, o governo pode refazer as suas contas. Então, normalmente, no início do ano, o governo, mais especificamente esses três ministérios chave que são Fazenda, Planejamento e Casa Civil, definem o chamado limite orçamentário, ou para um ano todo ou para um determinado período, e o presidente da república emite um decreto estabelecendo esses limites por órgãos e não por programa ou por ações. Então a gente trabalha com esse limite" (Entrevista concedida aos autores em 06 de fevereiro de 2012. Digit.).

Esse tipo de sistema acarreta alguns transtornos para o gestor da política. O primeiro deles é que não há uma regularidade na disponibilidade dos recursos financeiros, embora haja regularidade orçamentária. Segundo, o pagamento ocorre de modo efetivo à medida que há recursos em caixa, liberado de acordo com autorização do Ministério do Planejamento. Além disso, existem restrições para a execução orçamentária que somente são liberadas no final do ano, o que dificulta sua execução. Ocorre então que a Senaes, principalmente no PPA 2008-2011, sempre tem um volume grande de recursos a pagar, referente aos compromissos contratados no ano anterior. Soma-se a isso o fato de a Sanaes, além de efetuar tais pagamentos, ter de executar o orçamento do ano em exercício, criando assim um efeito "bola de neve".

Passando para a análise das ações do PESD, verificou-se que ocorreram algumas alterações entre os dois PPAs. Com isso, optou-se por verificar a natureza, o valor e a execução orçamentária das ações do programa separadas por PPA. A Tabela 2, a seguir, fornece o valor e a execução orçamentária por projeto do PESD entre os anos de 2004 e 2007. Do orçamento total aprovado (R $\$ 89157$ 502) a Senaes conseguiu executar, nesse período, $81,03 \%$. O ano de 2004, primeiro ano que o PESD conta com orçamento próprio para as suas ações, foi também o de menor percentual de execução, 60,8\%. Já no ano de 2006, a Senaes alcançou o maior índice de execução orçamentária, com 97,8\%. Entre os projetos do PESD no PPA 2004-2007, a ação que concentrou a maior parte dos recursos em termos de dotação orçamentária foi a 4737 - Fomento à Geração de Trabalho e Renda em Atividades de Economia Solidária, com $66,5 \%$ do orçamento total. A segunda ação a receber mais investimentos foi a 8275 - Recuperação de Empresas por Trabalhadores Organizados em Autogestão, com 12,1\% do total. As demais ações do programa receberam uma porcentagem do orçamento que não ultrapassou $6 \%$ do valor total, todavia, foram aquelas com o maior percentual de execução. Contrariamente, a ação que recebeu o maior volume de recursos, a 4 737, não chegou a executar $50 \%$ de seus recursos.

TABELA 2 - VALOR E EXECUÇÃO ORÇAMENTÁRIA POR PROJETO DO PESD: PPA 2004-2007

\begin{tabular}{|l|l|c|c|c|c|c|}
\hline Projetos - PPA & & $\mathbf{2 0 0 4}$ & $\mathbf{2 0 0 5}$ & $\mathbf{2 0 0 6}$ & $\mathbf{2 0 0 7}$ & Total \\
\hline 980 - Apoio à & Orçam. (R\$) & 2025454 & 906536 & 710080 & 1536874 & 5178944 \\
Constituição e & \% Total & 7,0 & 6,9 & 5,5 & 4,5 & 5,8 \\
Consolidação de & \% Exec. & 77,3 & 3,4 & 99,6 & 96,7 & 73,2 \\
Políticas Públicas de & & & & & & \\
Economia Solidária & & & & & & \\
\hline 2272 - Gestão e & Orçam. (R\$) & 1554131 & 400971 & 448000 & 400000 & 2803102 \\
Administração do & \% Total & 5,3 & 3,0 & 3,5 & 1,2 & 3,1 \\
Programa & \% Exec. & 92,1 & 62,2 & 72,9 & 99,3 & 85,8 \\
\hline
\end{tabular}

\footnotetext{
4 Para fins deste trabalho, a execução orçamentária foi calculada como o percentual entre o total de recursos liquidados no exercí-
}

cio administrativo em relação ao total de recursos previstos inicialmente pela LOA. 


\begin{tabular}{|c|c|c|c|c|c|c|}
\hline 2A84 - Sistema & Orçam. (R\$) & 0 & 0 & 784000 & 424821 & 1208821 \\
\hline Nacional de & $\%$ Total & 0 & 0 & 6,1 & 1,3 & 1,4 \\
\hline \multicolumn{6}{|l|}{ Economia Solidária } & 96,8 \\
\hline \multirow{3}{*}{$\begin{array}{l}\text { 2A85 - Capacitação } \\
\text { de Agentes de } \\
\text { Desenvolvimento } \\
\text { Solidário }\end{array}$} & Orçam. (R\$) & 0 & 0 & 274000 & 2400239 & 2674239 \\
\hline & $\%$ Total & 0 & 0 & 2,1 & 7,1 & 3,0 \\
\hline & $\%$ Exec. & 0 & 0 & 81,8 & 77,7 & 78,1 \\
\hline \multirow{3}{*}{$\begin{array}{l}4641 \text { - Publicidade } \\
\text { de Utilidade Pública }\end{array}$} & Orçam. (R\$) & 593884 & 397121 & 230000 & 207000 & 1428005 \\
\hline & $\%$ Total & 2,0 & 3,0 & 1,8 & 0,6 & 1,6 \\
\hline & $\%$ Exec. & 40,7 & 52,3 & 60,5 & 0 & 41,2 \\
\hline \multirow{3}{*}{$\begin{array}{l}4736 \text { - Funcionamento } \\
\text { do Conselho Nacional } \\
\text { de Economia Solidária }\end{array}$} & Orçam. (R\$) & 396399 & 399552 & 0 & 0 & 795951 \\
\hline & $\%$ Total & 1,4 & 3,0 & 0 & 0 & 0,9 \\
\hline & $\%$ Exec. & 100,0 & 73,4 & 0 & 0 & 86,6 \\
\hline \multirow{3}{*}{$\begin{array}{l}4737 \text { - Fomento à } \\
\text { Geração de Trabalho } \\
\text { e Renda em Atividades } \\
\text { de Ecomomia Solidária }\end{array}$} & Orçam. (R\$) & 20566250 & 8959154 & 8819440 & 20916542 & 59261386 \\
\hline & $\%$ Total & 70,6 & 67,8 & 68,5 & 61,6 & 66,5 \\
\hline & \% Exec. & 44,1 & 67,5 & 92,1 & 24,6 & 47,9 \\
\hline \multirow{3}{*}{$\begin{array}{l}4739 \text { - Promoção do } \\
\text { Consumo Ético e } \\
\text { Comércio Justo }\end{array}$} & Orçam. (R\$) & 2484738 & 368617 & 1232000 & 808473 & 4893828 \\
\hline & $\%$ Total & 8,5 & 2,8 & 9,6 & 2,4 & 5,5 \\
\hline & \% Exec. & 58,5 & 99,9 & 100 & 99,9 & 78,9 \\
\hline \multirow{3}{*}{$\begin{array}{l}4744 \text { - Assistência } \\
\text { Técnica para Geração } \\
\text { de Finanças Solidárias }\end{array}$} & Orçam. $(\mathrm{R} \$)$ & 489602 & 154979 & 0 & 0 & 644581 \\
\hline & $\%$ Total & 1,7 & 1,2 & 0 & 0 & 0,7 \\
\hline & \% Exec. & 87,2 & 100 & 0 & 0 & 90,3 \\
\hline \multirow{3}{*}{$\begin{array}{l}6540 \text { - Ações } \\
\text { Emergenciais de } \\
\text { Geração de Trabalho } \\
\text { e Renda }\end{array}$} & Orçam. (R\$) & 2000000 & 0 & 0 & 0 & 2000000 \\
\hline & \%Total & 6,9 & 0 & 0 & 0 & 2,2 \\
\hline & \% Exec. & 90,3 & 0 & 0 & 0 & 90,3 \\
\hline \multirow{4}{*}{$\begin{array}{l}8275 \text { - Recuperação } \\
\text { de Empresas por } \\
\text { Trabalhadores } \\
\text { Organizados } \\
\text { em Autogestão }\end{array}$} & Orçam. (R\$) & 0 & 1633470 & 1848000 & 7262051 & 10743521 \\
\hline & $\%$ Total & 0 & 12,4 & 14,4 & 21,4 & 12,1 \\
\hline & \% Exec. & 0 & 96,4 & 98,7 & 97,3 & 97,4 \\
\hline & & & & & & \\
\hline \multirow[t]{3}{*}{ Total Senaes } & Orçam. (R\$) & 29110458 & 13220400 & 12870644 & 33956000 & 89157502 \\
\hline & $\%$ Total & 100 & 100 & 100 & 100 & 100 \\
\hline & \% Exec. & 60,8 & 77,4 & 97,8 & 94,1 & 81,03 \\
\hline
\end{tabular}

FONTE: Lei de Diretrizes Orçamentárias (2004 a 2007) (BRASIL. CÂMARA DOS DEPUTADOS, 2013).

Quando questionado sobre o percentual orçamentário destinado à ação 4737 - Fomento à Geração de Trabalho e Renda em Atividades de Economia Solidária, que recebeu $66,5 \%$ do orçamento total da secretaria -, o diretor da Senaes explicou que, naquele contexto, era imprescindível inserir ações no programa que sensibilizasse o Congresso Nacional e os demais órgãos do governo, como o Ministério do
Planejamento, da mesma forma que atendesse também à missão do MTE. Por isso, focou-se em uma ação explícita de geração de trabalho e renda. Dessa ação, ainda de acordo com a Senaes, outras estavam ligadas, como o apoio às ITCPs e a criação dos Centros Públicos de Economia Solidária, para a assistência técnica aos empreendimentos de economia solidária e redes de cooperação territoriais. 
No PPA 2008-2011, a distribuição dos recursos foi relativamente mais igualitária entre as ações do que no PPA anterior. Entre as 13 ações previstas no PESD (contra 11 no PPA anterior), a ação prioritária foi a 8 078 - Agentes de Desenvolvimento Solidário, que foi inserida nesse PPA, com aproximadamente $30 \%$ do orçamento total para o período. A distribuição do orçamento da Senaes no PPA 2008-2011 e sua execução, entre 2008 a 2010, podem ser vistas na Tabela 3, a seguir.

TABELA3 - VALOR E EXECUÇÃO ORÇAMENTÁRIA POR PROJETO DO PESD: PPA 2008-2010

\begin{tabular}{|c|c|c|c|c|c|}
\hline Projetos - PPA & & 2008 & 2009 & 2010 & Total \\
\hline 2272 - Gestão e & Orçam. (R\$) & 621273 & 620000 & 910000 & 2151273 \\
\hline Administração do & $\%$ Total & 1,5 & 2,3 & 2,0 & 1,9 \\
\hline Programa & $\%$ Exec. & 92,2 & 98,4 & 89,7 & 92,9 \\
\hline 2A84 - Cadastro de & Orçam. (R\$) & 3000000 & 2000000 & 1000000 & 6000000 \\
\hline Empreendimentos e & $\%$ Total & 7,2 & 7,5 & 2,2 & 5,3 \\
\hline $\begin{array}{l}\text { Entidades de Apoio para } \\
\text { Manutenção e Ampliação } \\
\text { do SIES }\end{array}$ & $\%$ Exec. & 100,0 & 24,1 & 0,0 & 58,0 \\
\hline 2A85 - Formação de & Orçam. (R\$) & 4750000 & 4650000 & 10745000 & 20145000 \\
\hline Formadores(as), & $\%$ Total & 11,5 & 17,3 & 23,8 & 17,8 \\
\hline $\begin{array}{l}\text { Educadores(as) e } \\
\text { Gestores Públicos para } \\
\text { Atuação em Economia } \\
\text { Solidária }\end{array}$ & \% Exec. & 36,9 & 59,4 & 23,8 & 35,1 \\
\hline 4641 - Publicidade de & Orçam. $(\mathrm{R} \$)$ & 0 & 0 & 500000 & 500000 \\
\hline Utilidade Pública & $\%$ Total & 0,0 & 0,0 & 1,1 & 0,4 \\
\hline & \% Exec. & 0,0 & 0,0 & 7,9 & 7,9 \\
\hline 4737 - Fomento e & Orçam. $(\mathrm{R} \$)$ & 5924100 & 3014130 & 2800000 & 11738230 \\
\hline Assistência Técnica a & $\%$ Total & 14,3 & 11,2 & 6,2 & 10,4 \\
\hline $\begin{array}{l}\text { Empreendimentos } \\
\text { Econômicos Solidários e } \\
\text { Redes de Cooperação } \\
\text { de Economia Solidária }\end{array}$ & \% Exec. & 0,1 & 0,1 & 0,0 & 0,1 \\
\hline 4739 - Organização & Orçam. $(\mathrm{R} \$)$ & 2562908 & 5388000 & 2100000 & 10050908 \\
\hline Nacional da & $\%$ Total & 6,2 & 20,1 & 4,7 & 8,9 \\
\hline $\begin{array}{l}\text { Comercialização dos } \\
\text { Produtos e Serviços de } \\
\text { Empreendimentos de ES }\end{array}$ & $\%$ Exec. & 0,0 & 51,4 & 43,8 & 36,7 \\
\hline 4827 - Desenvolvimento & Orçam. (R\$) & 401000 & 401000 & 380000 & 1182000 \\
\hline e Disseminação de & $\%$ Total & 1,0 & 1,5 & 0,8 & 1,0 \\
\hline $\begin{array}{l}\text { Conhecimentos e } \\
\text { Tecnologias Sociais } \\
\text { Apropriadas à Economia } \\
\text { Solidária }\end{array}$ & \% Exec. & 99,8 & 0,0 & 16,4 & 39,1 \\
\hline 4850 - Fomento a & Orçam. (R\$) & 2800000 & 1250000 & 2200000 & 6250000 \\
\hline Incubadoras de & $\%$ Total & 6,8 & 4,7 & 4,9 & 5,5 \\
\hline $\begin{array}{l}\text { Empreendimentos } \\
\text { Econômicos Solidários }\end{array}$ & $\%$ Exec. & 59,0 & 24,0 & 13,0 & 35,8 \\
\hline
\end{tabular}




\begin{tabular}{|c|c|c|c|c|c|}
\hline $\begin{array}{l}8056 \text { - Fomento às } \\
\text { Finanças Solidárias com } \\
\text { Base em Bancos } \\
\text { Comunitários e } \\
\text { Fundos Solidários }\end{array}$ & $\begin{array}{l}\text { Orçam. (R\$) } \\
\% \text { Total } \\
\% \text { Exec. }\end{array}$ & $\begin{array}{c}2412907 \\
5,8 \\
0,4\end{array}$ & $\begin{array}{c}2249528 \\
8,4 \\
0,0\end{array}$ & $\begin{array}{c}2729000 \\
6,1 \\
45,6\end{array}$ & $\begin{array}{c}7391435 \\
6,5 \\
17,0\end{array}$ \\
\hline $\begin{array}{l}8078 \text { - Agentes de } \\
\text { Desenvolvimento Solidário }\end{array}$ & $\begin{array}{l}\text { Orçam. }(\mathrm{R} \$) \\
\% \text { Total } \\
\% \text { Exec. }\end{array}$ & $\begin{array}{c}11850000 \\
28,6 \\
47,3\end{array}$ & $\begin{array}{c}8200000 \\
30,6 \\
25,5\end{array}$ & $\begin{array}{c}12876000 \\
28,6 \\
4,5\end{array}$ & $\begin{array}{c}32926000 \\
29,0 \\
25,1\end{array}$ \\
\hline $\begin{array}{l}8138 \text { - Implantação de } \\
\text { Centros Públicos de } \\
\text { Economia Solidária }\end{array}$ & $\begin{array}{l}\text { Orçam. }(\mathrm{R} \$) \\
\% \text { Total } \\
\% \text { Exec. }\end{array}$ & $\begin{array}{c}4739781 \\
11,4 \\
0,0\end{array}$ & $\begin{array}{c}3600000 \\
13,4 \\
0,0\end{array}$ & $\begin{array}{c}4085000 \\
9,1 \\
1,5\end{array}$ & $\begin{array}{c}12424781 \\
11,0 \\
0,5\end{array}$ \\
\hline $\begin{array}{l}8275 \text { - Recuperação } \\
\text { de Empresas por } \\
\text { Trabalhadores } \\
\text { Organizados em } \\
\text { Autogestão }\end{array}$ & $\begin{array}{l}\text { Orçam. }(\mathrm{R} \$) \\
\% \text { Total } \\
\% \text { Exec. }\end{array}$ & $\begin{array}{c}1800000 \\
4,3 \\
16,2\end{array}$ & $\begin{array}{c}1800000 \\
6,7 \\
0,0\end{array}$ & $\begin{array}{c}1950000 \\
4,3 \\
0,0\end{array}$ & $\begin{array}{c}5550000 \\
4,9 \\
5,3\end{array}$ \\
\hline $\begin{array}{l}8420 \text { - Estímulo à } \\
\text { Institucionalização de } \\
\text { Políticas Públicas de } \\
\text { Economia Solidária }\end{array}$ & $\begin{array}{l}\text { Orçam. }(\mathrm{R} \$) \\
\% \text { Total } \\
\% \text { Exec. }\end{array}$ & $\begin{array}{c}600000 \\
1,4 \\
34,6\end{array}$ & $\begin{array}{c}1511902 \\
5,6 \\
15,6\end{array}$ & $\begin{array}{c}2795000 \\
6,2 \\
75,0\end{array}$ & $\begin{array}{c}4906902 \\
4,3 \\
51,8\end{array}$ \\
\hline Total Senaes & $\begin{array}{l}\text { Orçam. }(\mathrm{R} \$) \\
\% \text { Total } \\
\% \text { Exec. }\end{array}$ & $\begin{array}{c}41461999 \\
100,0 \\
51,6\end{array}$ & $\begin{array}{c}26816303 \\
100,0 \\
77,3\end{array}$ & $\begin{array}{c}45070000 \\
100,0 \\
25,3\end{array}$ & $\begin{array}{c}113348302 \\
100,0 \\
49,3\end{array}$ \\
\hline
\end{tabular}

FONTE: Lei de Diretrizes Orçamentárias (2008 a 2010) (BRASIL. CÂMARA DOS DEPUTADOS, 2013).

Um fato importante ocorrido antes da consolidação da proposta da Senaes para o PPA 2008-2011 foi a elaboração do Mapeamento Nacional de Economia Solidária, concluído em 2007. Nele constam informações relevantes sobre a realidade dos empreendimentos de economia solidária no Brasil, sob as mais variadas dimensões. De acordo com o diretor da Senaes, o mapeamento foi importante ao dar à secretaria um diagnóstico atual dos empreendimentos, apontados por ele como "atores fundamentais do processo", e que apresentaram diversas fragilidades em termos sócio-organizativos, econômicos e políticos. Os resultados do Mapeamento, que formaram a base de dados do Siste-ma de Informações em Economia Solidária (SIES), deveriam subsidiar a reorientação das políticas da secretaria.

No entanto, a Senaes passou por uma série de dificuldades na execução de suas ações previstas no PPA 2008-2011. Primeiramente, percebe-se que a dificuldade de execução orçamentária da Senaes nesse período agravou-se, tendo nos últimos três anos uma média de execução que não chegou a 50\%. Nesse período, 2009 foi o ano com melhor índice de execução, com 77,3\%. Já o ano com o índice de execução mais baixo foi 2010 , com $25,3 \%$.
A pesquisa de campo possibilitou identificar algumas das principais dificuldades de execução da Senaes no PPA 2008-2011 que levaram a tal quadro. Uma delas diz respeito ao término do convênio entre a Senaes e Fundação Banco do Brasil (FBB) em 2007, que de certa forma permitia maior agilidade ao processo de execução das ações do programa. Desse ano em diante, a Senaes passou a fazer, diretamente, convênios com entidades privadas sem fins lucrativos, por meio de chamadas públicas. A mudança deveu-se ao fato do governo federal alterar as regras de repasse de recursos públicos para entidades da sociedade civil, com o Decreto n. 6 170 , de 25 de julho de 2007, que passou a regulamentar "os convênios, contratos de repasse e termos de cooperação celebrados pelos órgãos e entidades da administração pública federal com órgãos ou entidades públicas ou privadas sem fins lucrativos, para a execução de programas, projetos e atividades de interesse recíproco que envolvam a transferência de recursos oriundos do Orçamento Fiscal e da Seguridade Social da União".

Outro ponto foi a publicação em novembro de 2008 da Portaria Interministerial n. 127, que estabeleceu as normas para a execução do dispositivo do Decreto $n$. 6170 e colocou em prática o referido decreto com a 
implantação do Sistema de Gestão de Convênios e Contratos de Repasses (Siconv). Essas novas normativas apresentaram uma série de exigências e controles rigorosos na execução e condução dos convênios e contratos de repasses de recursos públicos junto às organizações da sociedade civil, acarretando em dificuldades iniciais de adaptação por parte dos órgãos que dependem dessas parcerias para executar seu orçamento.

Na Senaes, entre os anos de 2004 e 2010, houve um aumento de $450 \%$ do número de convênios celebrados com entidades da sociedade civil, como demonstra o Gráfico 2, a seguir. Esse aumento ocorreu principalmente entre 2008 e 2009 , fruto da entrada em vigor do Decreto n. 6170 e da Portaria Interministerial 127. Porém, em termos de estrutura interna, o aumento do número dos convênios não foi acompanhado pelo aumento proporcional do número de servidores, o que resultou na mudança da relação de servidores por convênio, que era próximo de cinco por um em 2005 e chegou a um servidor por convênio em 2010.

\section{GRÁFICO 2 - RELAÇÃO ENTRE SERVIDORES E CONVÊNIOS, SENAES (2003-2010)}

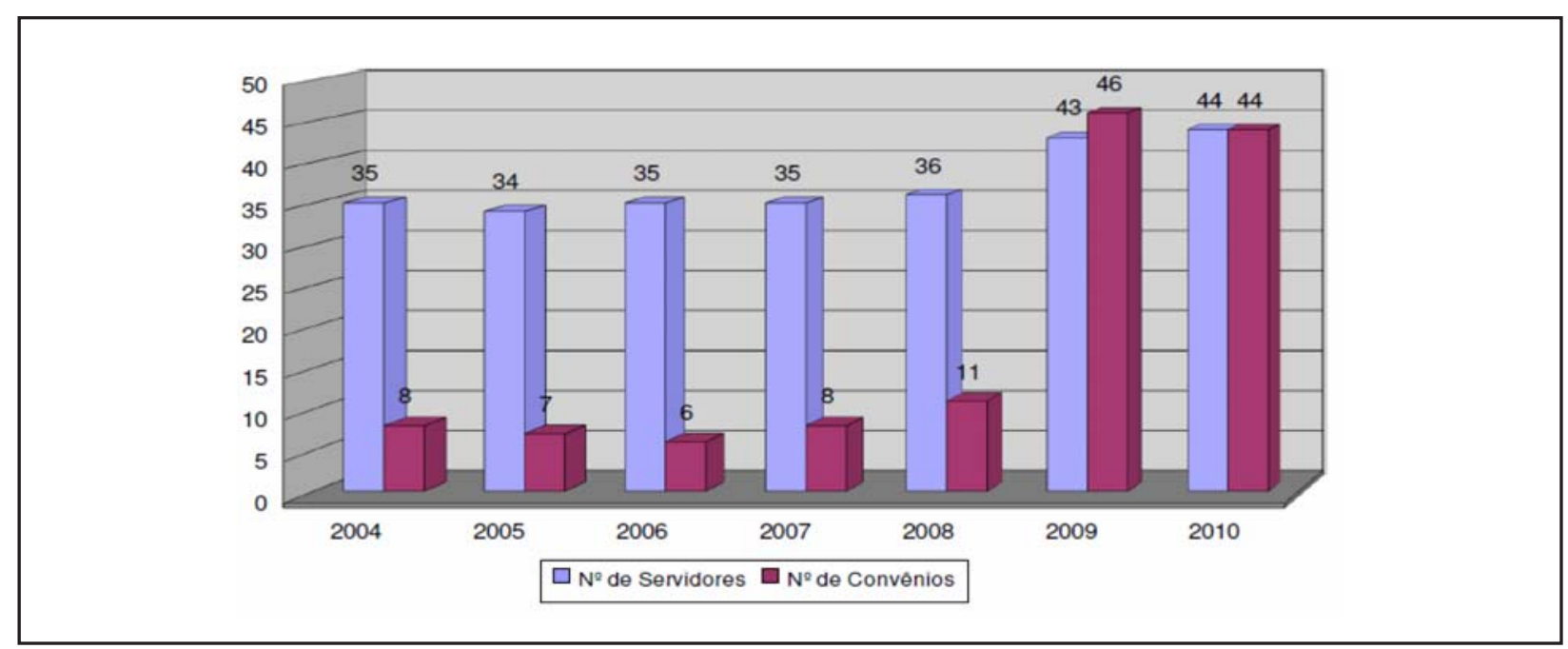

FONTE: Os autores, a partir de dados fornecidos pela Senaes.

O que se entende da discussão deste tópico é que os instrumentos orçamentários da Senaes, além de representarem um volume de recursos muito baixo para a efetivação de um programa nacional de cunho transversal, como almejava ser o PESD, comungam da mesma fragilidade de outras políticas sociais, já que seus recursos originariamente destinados pela LOA podem ser diminuídos por meio de cortes ou contingenciamentos ao longo do ano, de acordo o desejo do comando econômico do governo federal. Com isso, a possibilidade de descontinuidade das ações propostas ou em curso é muito grande, e a política vive em um estado de instabilidade, necessitando constantemente de negociações diversas com a cúpula de governo. $\mathrm{O}$ fortalecimento do mercado de trabalho assalariado permaneceu como prioridade do governo, cabendo à Senaes apenas um papel residual, quase simbólico, como mostram os dados sobre dotação e execução orçamentária do MTE. Pela Tabela 4, a seguir, nota-se que dois dos principais indicadores de avaliação do mercado de trabalho tiveram uma evolução positiva entre 2003 e 2010, revertendo a tendência vinda da década anterior, conforme já mostrado na Tabela 1. A taxa de desemprego aberto caiu de $12,1 \%$ para $6,6 \%$, enquanto o grau de informalidade dos postos de trabalho caiu de $41,7, \%$ para $36,1 \%$, no final do período.

TABELA 4 - TAXAS DE DESEMPREGO E INFORMALIDADE NO BRASIL: 2003-2010 (\%)

\begin{tabular}{|l|c|c|c|c|c|c|c|c|}
\hline Ano & $\mathbf{2 0 0 3}$ & $\mathbf{2 0 0 4}$ & $\mathbf{2 0 0 5}$ & $\mathbf{2 0 0 6}$ & $\mathbf{2 0 0 7}$ & $\mathbf{2 0 0 8}$ & $\mathbf{2 0 0 9}$ & $\mathbf{2 0 1 0}$ \\
\hline Desemprego aberto & 41,7 & 42,4 & 42,2 & 41,2 & 40,6 & 38,3 & 37,5 & 36,1 \\
Informalidade & 12,1 & 11,2 & 9,7 & 9,8 & 9,1 & 7,7 & 7,9 & 6,6 \\
\hline
\end{tabular}

Fonte: IPEA (2010). 
Esse desprestígio da Senaes e da economia solidária em geral também foi diagnosticado por Novaes (2008), que o levou a argumentar que a Senaes seria uma espécie de "pedra protosocialista num colar declaradamente pró-capital", para caricaturar a pouca relevância que essa temática possui no rol de estratégias de desenvolvimento do governo federal, embora permanecesse na agenda governamental.

\section{IV.3. As parcerias institucionais em torno da economia solidária no governo federal}

Além das ações que compõem o PESD, a Senaes busca estabelecer parcerias com outras estruturas de governo para implementar ações de economia solidária. O principal órgão que ela dispõe para efetuar essa interlocução institucional é o Conselho Nacional de Economia Solidária (CNES), criado por meio do Decreto n. 5 811, de 21 de julho de 2006. O CNES é um órgão colegiado integrante da estrutura do MTE, de natureza consultiva e propositiva, e possui a incumbência de realizar a interlocução e buscar consensos em torno de políticas e ações de fortalecimento da economia solidária no Brasil. No que diz respeito a sua composição, estão presentes representantes de instâncias de governo (federal, estaduais e municipais), empreendimentos econômicos solidários e organizações da sociedade civil.

Em geral, as demais ações de economia solidária no governo federal são executadas de duas formas distintas: em algumas delas, a Senaes executa em parceria com outras estruturas de governo; em outras, a Senaes apóia direta ou indiretamente, mas a execução fica a cargo da estrutura responsável. No caso das primeiras, elas integram programas de outros ministérios que são executados em parceria com a Senaes, por meio de destaque orçamentário, ou seja, a transferência de recursos destinados pela LOA de outra entidade da administração pública para a Senaes. Como exemplo dessas ações, pode-se citar: o PRONASCI Economia Solidária (Ministério da Justiça); o Fomento para a Organização de Cooperativas Atuantes com Resíduos Sólidos (Ministério das Cidades) e a parceria com o Ministério da Ciência e Tecnologia, por meio da Finep, para o apoio ao Programa Nacional de Incubadoras de Cooperativas Populares (PRONINC).

No caso da outra possibilidade, a Senaes apóia institucionalmente algumas ações de outros ministérios. Os principais parceiros nesse caso são: o Ministério do Desenvolvimento Social e Combate à Fome (MDS), com suas ações de inclusão produtiva de parcelas da população em situação de pobreza; o Ministério do Meio Ambiente (MMA), com ações ligadas à Agenda XXI e o Ministério do Desenvolvimento Agrário (MDA), com suas ações de cooperativismo e apoio aos empreendimentos de agricultura familiar. No caso da parceria com o MDA, essa é considerada como estratégica pelo diretor entrevistado da Senaes, ainda mais pelo fato de que, embora a Senaes tenha como foco principal o público excluído do mercado de trabalho formal urbano, o Mapeamento apontou que a realidade da economia solidária no Brasil possui uma forte ligação com o meio rural.

A definição de que o público prioritário para as ações da Senaes seriam os trabalhadores urbanos ocorreu porque, no ato de criação do $\mathrm{PESD}$, sua justificativa não poderia sobrepor-se à de outra ação já existente no governo federal. E, no Brasil, o fomento ao cooperativismo já era definido como de responsabilidade do Departamento Nacional de Cooperativismo (Denacoop), ligado ao Ministério da Agricultura, Pecuária e Abastecimento (MAPA). No entanto, o cooperativismo apoiado pelo Denacoop não convergem com a estratégia de cooperativismo popular defendida pela economia solidária, já que se baseia na Lei n. 5 764, conhecida como Lei Geral do Cooperativismo, a qual foi promulgada no Brasil em 1971, como resultado das discussões em que envolveram as grandes cooperativas agrícolas em pleno auge da modernização agrícola brasileira. Desde então, apesar das constantes pressões formuladas em propostas de modificação, não sofreu alterações e adequações significativas, mesmo diante das transformações e emergências de novas formas de organização do trabalho associado no Brasil.

Entre as várias polêmicas em discussão em torno da legislação cooperativista em vigor, dois itens são vistos pelos grupos de apoio à economia solidária como extremamente restritivos para a formalização de novas cooperativas ${ }^{5}$. Uma delas é a exigência da inscrição da cooperativa nas Juntas Comerciais de cada estado, que são localizadas nas capitais e, com isso, torna-se um complicador para grupos associativos nos municípios interioranos. A segunda diz respeito à exigência de um mínimo de 20 associados para a constituição da cooperativa, já que o próprio Mapeamento feito pela Senaes aponta que boa parte dos empreendimentos possui um número inferior a esse. Atualmente, encontra-se em trâmite no Congresso Nacional duas propostas de revisão do marco legal do cooperativismo, com artigos que visam permitir uma maior flexibilidade para que novos grupos possam inserir-se formalmente nessa estratégia. Como em termos de planejamento não há diferença entre cooperativismo "empresarial" e

\footnotetext{
5 De acordo com a Senaes, apenas 10\% dos 21859 empreendimentos de economia solidária mapeados são devidamente formalizados na figura jurídica de uma cooperativa.
} 
cooperativismo "popular", a diferenciação no âmbito do PPA precisou ser realizado em termo rural, no caso o Denacoop, e urbano, caso da Senaes. Essa diferenciação acarretou em perdas políticas para a Senaes, sobretudo com relação aos movimentos sociais da agricultura familiar, que, embora carreguem em seu nome a marca economia solidária, caso da União das Cooperativas da Agricultura Familiar e Economia Solidária (Unicafes), estão mais ligados politicamente ao MDA, que, por sua vez, concentra as políticas públicas que beneficiam os agricultores mais diretamente. Esse tipo de relação, de acordo com Costa (2008, p. 98), "causa a perda de autonomia das organizações sociais, que direcionam suas ações em funções das possibilidades que o governo lhe oferece".

Portanto, o que se identifica é que as parcerias institucionais que gravitam em torno da Senaes, embora sejam importantes, são frágeis e resultam em ações de pouco vulto para o fortalecimento político-institucional da economia solidária como marca política no governo federal. Com isso, aliado às dificuldades já relatadas de execução orçamentária, a política de economia solidária no Brasil não corresponde às suas próprias diretrizes, de buscar um novo modelo de desenvolvimento, pois, para ser o "novo", deveria representar uma ameaça ao "velho" modelo de desenvolvimento capitalista, fato que não ocorre na arena política brasileira. Costa (idem) também chegou à conclusão semelhante, e citou como indicativo o fato de não ter sido aprovada nenhuma lei que tratasse especificamente de economia solidária, a não ser de forma indireta ${ }^{6}$. Nem mesmo a Lei Geral do Cooperativismo, que segue beneficiando as grandes cooperativas agrícolas e restringindo de diversas formas a maior popularização do cooperativismo no país, foi alterada nesses últimos oito anos, por se tratar de um tema que envolve distintos interesses, e o governo federal não parece estar disposto a ver embates em sua base partidária de sustentação (que por sinal, é de uma amplitude ideológico-partidária considerável) por algo que não lhe seja prioritário.

\section{CONCLUSÕES}

Este trabalho buscou compreender a forma como a temática da economia solidária foi adotada pela agenda governamental. Primeiramente, diagnosticou-se que o processo de inserção da economia solidária como política pública pelo governo federal em 2003, com o lançamento do PESD, segue muito claramente o modelo

\footnotetext{
6 Atualmente há uma mobilização, coordenada pelo FBES, para a aprovação da Lei da Economia Solidária. O texto do projeto de lei pode ser consultado no endereço eletrônico: http:// cirandas.net/leidaecosol/texto-da-lei. Acesso em: 3.jun.2013.
}

proposto por Kingdon (1995). Entretanto, a inserção de um programa de política pública na agenda é apenas uma etapa de seu ciclo. Definida sua constituição normativa, o programa segue sua luta interna em busca da consolidação da marca política que ele representa e na disputa pelos recursos limitados do governo. Com isso, uma política pública está sempre em estado de instabilidade, pois ela remete a um problema que pode não mais ser visto como tal, ou outras soluções podem despontar como mais apropriadas para resolvê-lo, de modo que a política pública em curso pode ser descartada ou relegada a um papel cada vez mais marginal na estrutura político-administrativa.

E pelos resultados desta investigação, parece ser esse o processo que está vivendo a política de economia solidária no governo federal. Passados os primeiros oito anos, não se observou uma real intervenção do governo ao ponto de consolidar as práticas socioeconômicas - difundidas pela economia solidária - como estratégia real para a inserção no mundo do trabalho, ou mesmo criar um ambiente institucional que incentive a formalização dos grupos econômicos associativos existentes e os que estariam por surgir.

A Senaes, órgão do governo responsável pela elaboração e execução do PESD, não foi estruturada adequadamente nesse período. Com isso, mesmo possuindo uma baixa dotação orçamentária, quando comparada com outros programas do MTE, a secretaria apresentou dificuldades de execução orçamentária, resultante, por um lado, de problemas estruturais internos, e de outro, pela própria fragilidade das políticas sociais no Brasil, cujo orçamento previamente definido pela LOA está sempre sujeito a cortes e contingenciamentos de acordo com as diretrizes fiscais estabelecidas pelo centro econômico do governo. Tais fragilidades não permitiram que o PESD se constituísse em um programa de referência para uma nova estratégia de desenvolvimento, se limitando a ações esparsas e fragmentadas que, embora tenham alcançado resultados positivos em alguns setores e junto a alguns grupos específicos, ainda são frágeis e insuficientes para sua maior incidência em âmbito nacional.

Os resultados desta investigação demonstraram também a heterogeneidade que, em geral, caracterizam os governos, formados por forças políticas e ideológicas distintas e até mesmo conflitantes em alguns pontos. Porém, mesmo abrangendo vários problemas e soluções em sua agenda, são poucas as prioridades que ascendem ao seu macrossistema político, enquanto os demais programas gravitam em um campo marginal, fora desse núcleo, em busca de espaço para sua valorização interna, como ocorre atualmente com a política de economia solidária. Enquanto ela for encarada meramente como uma alternativa paliativa 
ao problema do desemprego, voltada apenas para grupos excluídos e de difícil inserção no mercado de trabalho assalariado, mesmo com todo o esforço da Senaes em caracterizá-la como a afirmação de uma nova proposta de desenvolvimento, dificilmente conseguirá enfrentar os antagonismos e conflitos de interesse que impedem sua viabilização.

Isso posto, a economia solidária tenderia a perder ainda mais espaço, dado que o mercado de trabalho reestruturou-se significativamente ao longo desse período, atraindo inclusive os trabalhadores de menor qualificação. As variáveis que caracterizam o mercado de trabalho atual apresentam uma realidade distinta daquela que lhe garantiu a abertura da janela de oportunidade na agenda de governo em 2003, mesmo sabendo que essas variáveis (nível de ocupação, desemprego e informalidade) são dependentes da conjuntura econômica (interna e externa), ou seja, sujeitas a inúmeras incertezas.

Por outro lado, ressalta-se também que, apesar de todas as dificuldades quanto a recursos e instrumentos institucionais, a Senaes conseguiu aglutinar ao seu entorno forças sociais e políticas importantes para a defesa da economia solidária enquanto política pública. A realização de conferências, plenárias e feiras nacionais, com participação de representantes de entidades de apoio e empreendimentos de todo o Brasil, além da disseminação das incubadoras de cooperativas populares em universidades públicas e privadas, são exemplos dessa luta que, de alguma forma, divulgaram o termo e toda sua simbologia no território nacional. Todo esse esforço foi importante para a manutenção, ainda que de forma marginal, da temática da economia solidária enquanto marca política presente na agenda governamental.

Sob nosso entendimento, a economia solidária deve ser tomada como uma alternativa real de organização para o trabalho dos mais diversos grupos sociais, independentemente de sua condição socioeconômica, de modo a consolidar-se como uma estratégia de desenvolvimento endógeno, com a flexibilidade necessária para sua incidência e enraizamento nos mais distintos contextos territoriais do país. Mas, dados os distintos interesses que envolvem uma decisão desse nível, isso somente seria possível com uma adesão clara do núcleo de decisão do governo no enfrentamento de alguns desafios importantes, tais como: (i) a definição de um ambiente institucional propício para a formalização desses empreendimentos em cooperativas; (ii) o estabelecimento de canais de financiamento adequados para sua realidade (a exemplo do Pronaf, na agricultura familiar); (iii) a criação de programas de assistência técnica com capilaridade em todo o território nacional e que dêem suporte aos empreendimentos nos mais diversos setores necessários ao seu negócio e sua forma de organização; (iv) maior possibilidade de acesso a mercados institucionais, por meio de compras públicas, que possam garantir a viabilidade inicial e o desenvolvimento desses empreendimentos, entre outras ações que podem ser derivadas do próprio Mapeamento elaborado pela Senaes. As necessidades listadas poderiam ser divididas em ações de curto e longo prazo, abordando desde o apoio a empreendimentos já consolidados até a construção de uma cultura cooperativista para o trabalho no Brasil.

Fernanda Abreu Nagem (fernandanagem@yahoo.com.br) é Doutoranda em Ciências Sociais pela Universidade Federal Rural do Rio de Janeiro (UFRRJ).

Sandro Pereira Silva (sandro.pereira@ipea.gov.br) é Doutorando em Ciências Sociais pela Universidade de Brasília $(\mathrm{UnB})$.

\section{REFERÊNCIAS BIBLIOGRÁFICAS}

ARRETCHE, M. 2002. Federalismo e relações intergovernamentais no Brasil: a reforma de programas sociais. Dados, Rio de Janeiro, v. 45, n. 3, p. 431-458. Disponível em: http://www.scielo.br/ $\mathrm{pdf} / \mathrm{dados} / \mathrm{v} 45 \mathrm{n} 3 / \mathrm{a} 04 \mathrm{v} 45 \mathrm{n} 3 . \mathrm{pdf}$. Acesso em: 30.maio.2013.

BERTUCCI, J. O. 2010. A produção de sentido e a construção social da economia solidária. Brasília. Tese (Doutorado em Sociologia). Universidade de Brasília.
CASTEL, R. 1998. As metamorfoses da questão social. Petrópolis: Vozes.

COSTA, M. 2008. Formação da agenda governamental: as políticas públicas de economia solidária no Brasil e na Venezuela. Brasília. Dissertação (Mestrado em Administração). Universidade de Brasília.

FEDOSSEIEV, P. N. 1973. Karl Marx. Lisboa: Avante.

FRANÇA FILHO, G. C. 2006. Políticas públicas de 
economia solidária no Brasil: características, desafios e vocação. In: FRANÇA FILHO, G. C. \& LAVILLE, J. Ação Pública e Economia Solidária: uma perspectiva internacional. Porto Alegre: UFRGS.

FRANÇA FILHO, G. C. \& LAVILLE, J. 2006. Ação pública e economia solidária: uma perspectiva internacional. Porto Alegre: UFRGS.

GAIGER, L. G. 2003. A economia solidária diante do modo de produção capitalista. Cadernos $C R H$, Salvador, v. 16, n. 39, p. 181-211, jul.-dez. Disponível em: http://www.cadernocrh.ufba.br/include/ getdoc.php?id $=967 \&$ article $=171 \&$ mode $=$ pdf\&OJSSID $=8$ 08a849d2d41f4a6e6bb466a4d169546. Acesso em: 30.maio.2013.

HADDAD, F. 2003. Sindicatos, cooperativas e socialismo. São Paulo: P. Abramo.

KINGDON, J. W. 1995. Agendas, Alternatives and Public Policies. Reading: Addison Wesley Longman.

LAVILLE, J. \& FRANÇA FILHO, G. C. 2004. Economia solidária: uma abordagem internacional. Porto Alegre: UFRGS.

LEITE, M. P. A. 2009. Economia solidária e o trabalho associativo: teorias e práticas. Revista Brasileira de Ciências sociais, São Paulo, v. 24, n. 69, p. 31-51, fev. Disponível em: http:/www.scielo.br/ pdf/rbcsoc/v24n69/03.pdf. Acesso em: 29.maio.2013.

MANCE, E. 1999. A revolução das redes: a colaboração solidária como uma alternativa pós-capitalista à globalização atual. Petrópolis: Vozes.
MATtOSO, J. 1999. A desordem do trabalho. São Paulo: Scritta.

NAGEM, F. A. 2011. Os caminhos do Programa Economia Solidária em Desenvolvimento. Viçosa. Dissertação (Mestrado em Extensão Rural). Universidade Federal de Viçosa.

NOVAES, H. 2008. Uma pedra proto-socialista num colar pró-capital financeiro: notas sobre a política pública de economia solidária no governo Lula. Trabalho apresentado no VI Encontro Internacional de Economia Solidária, realizado na cidade de São Paulo, de 25 a 27 de julho. Digit.

OLIVEIRA, F. 2009. Economia e política das finanças públicas no Brasil. São Paulo: Hucitec.

QUIJANO, A. 2002. Sistemas alternativos de produção? In: SOUZA SANTOS, B. (org.). Produzir para viver. São Paulo: Civilização Brasileira.

RAZZETO, L. 1997. Los caminhos de la economia solidária. Buenos Aires: Lumen-Hvmanitas.

SILVA, S. P. 2010. A economia solidária e os desafios da gestão pública: uma análise do programa oportunidade solidária no município de São Paulo. Revista Otra Economia, Buenos Aires, v. 4, n. 7, p. 62-82, $2^{\circ}$ semestre.

SINGER, P. 2002. Introdução à economia solidária. São Paulo: P. Abramo.

SOUZA, C. 2006. Políticas públicas: uma revisão de literatura. Revista Sociologias, Porto Alegre, ano 8, n. 16, p. 20-45, jul.-dez. Disponível em: http:// www.scielo.br/pdf/soc/n16/a03n16.pdf. Acesso em: 30.maio.2013.

\section{OUTRAS FONTES}

BRASIL. CÂMARA DOS DEPUTADOS. 2013. Orçamento Brasil. O portal do orçamento público. Lei de diretrizes orçamentárias - LDO. Disponível em: http://www2.camara.leg.br/atividadelegislativa/orcamentobrasil/ldo/ldo2014. Acesso em: 3.jun. 2013.

IPEA. 2004. Geração de empregos e realocação espacial no mercado de trabalho brasileiro - 1992-2002. Texto para discussão, Rio de Janeiro, n. 1 027, p.
1-23, jul. Disponível em: http://www.ipea.gov.br/ portal/images/stories/PDFs/TDs/td_1027.pdf. Acesso em: 3.junho.2013.

. 2010. Boletim de Mercado de Trabalho, Rio de Janeiro, n. 46, p. 1-63. Disponível em: http:// www.ipea.gov.br/portal/images/stories/PDFs/ mercadodetrabalho/bmt46_completo.pdf. Acesso em: 3.jun.2013. 
INSTITUTIONALIZATION AND IMPLEMENTATION OF PUBLIC POLICIES OF SOLIDARITY ECONOMY IN BRAZIL

\section{Fernanda Abreu Nagem and Sandro Pereira Silva}

The paper investigates the policy of solidarity economy in the federal government, implemented since 2003 with the creation of the National Secretariat of Solidarity Economy (SENAES). Based on the theoretical model of Kingdon (1995), the article examines, first, the political process (in a broad sense) who succeeded his inclusion as a public policy to generate jobs and income. Next, we analyze the projects and actions developed in the program between 2003 and 2010, with emphasis on their guidelines, internal structure, budget allocation and executionFinally, the article analyzes also what the main partners of SENAES these years to the development of other programs that interface with the solidarity economy, and thus could improve the adherence of the subject within the government. The analysis suggests that the model of Kingdon explains the process of inserting the solidarity economy as public policy in 2003, although this insertion is only one stage of the cycle. Defined its constitution rules, there is a dispute of the program within the government: past eight years, there was no effective intervention of the government to the point of consolidating the socio-economic practices - broadcast by solidarity economy - as a strategy for entering the real world work, or even create an institutional environment that encourages the formalization of associative economic groups. Despite its low budget allocation compared to other programs MTE, the PESD was not constituted as a 
referral program to a new development strategy, even if the SENAES has managed to coalesce around their important social and political forces for the defense of solidarity economy as a public policy. It shows and discusses the integration of policies and conduct of solidarity economy in the federal government, revealing that the issue did not rise to the macro-political, gravitating in a marginal field, outside the core, in search of space for your internal valuation. While it is regarded merely as a palliative alternative to the problem of unemployment, can hardly meet the antagonisms and conflicts of interest that prevent their development.

KEYWORDS: Solidarity economy; public policy; public budget; employment and income; associations. 